\title{
The Potential of Rats and Bats as Reservoirs of Leptospirosis and Japanese Encephalitis (JE) in Muna Region, Southeast Sulawesi Province, Indonesia
}

\author{
Anis Nur Widayati ${ }^{1}$, Made Agus Nurjana ${ }^{1}$, Aryo Ardanto $^{2}$, Ristiyanto ${ }^{2}$, \\ Pandji Wibawa Dhewantara ${ }^{3} \&$ April Hari Wardhana ${ }^{4,5}$ \\ ${ }^{1}$ Donggala Health Research and Development Center, Donggala, National Institute of Health Research and \\ Development, Ministry of Health of Indonesia, Donggala, Central Sulawesi, Indonesia \\ ${ }^{2}$ Center for Research and Development of Disease Vectors and Reservoirs (B2P2VRP), National Institute of \\ Health Research and Development, Ministry of Health of Indonesia, Salatiga, Central Java, Indonesia \\ ${ }^{3}$ Center for Public Health Research and Development, National Institute of Health Research and Development, \\ Ministry of Health of Indonesia, Jakarta, Indonesia \\ ${ }^{4}$ Indonesian Research Center for Veterinary Science, Indonesian Agency of Agricultural Research and \\ Development, Bogor, Indonesia \\ ${ }^{5}$ Faculty of Veterinary Medicine, University of Airlangga, Surabaya \\ Correspondence: Anis Nur Widayati, Donggala Health Research and Development Center, Donggala District, \\ Indonesia. Tel: 62-813-2884-8488.
}

Received: September 21, 2020 Accepted: November 5, 2020 Online Published: November 17, 2020

doi:10.5539/gjhs.v12n13p125

URL: https://doi.org/10.5539/gjhs.v12n13p125

\begin{abstract}
Background: Small mammals such as rats and bats are important animal reservoirs of various zoonotic diseases of public health importance. The potential of rats and bats as a reservoir of leptospirosis and Japanese Encephalitis (JE) in Muna Regency remains unknown. This study aimed to determine the presence of Leptospira spp and JE virus (JEV) in rats and bats in Muna Regency, Southeast Sulawesi Province.
\end{abstract}

Methods: A cross-sectional survey was carried out in three districts, namely Kabawo, Batalaiworu, and Katobu. Bats and rats were caught in six ecosystems spread across the three districts. Serological (Microscopic Agglutination Test, MAT) and molecular examinations (Polymerase Chain Reactions, PCR) were performed to detect Leptospira spp. and JEV in rats and bats, respectively.

Results: A total of 137 rats from seven species were successfully caught, namely Mus sp., Rattus argentiventer, R. nitidus, $R$. exulans, $R$. hoffmanni, $R$. norvegicus, and $R$. tanezumi. Of which, six species were confirmed positive for Leptospira spp by PCR, with the highest prevalence was found in $R$. argentiventer (50\%) and $R$. tanezumi (36.4\%). Meanwhile, a total of 86 bats were also successfully captured. The JEV antibody was detected in $D$. viridis, R. celebensis and S. wallacei.

Conclusion: Rats and bats are the potential reservoirs of leptospirosis and JE in Muna Regency. Most importantly, the study provides the first evidence of JE reservoirs (R. celebensis and S. wallacei) in Sulawesi. Surveillance of leptospirosis and JE are recommended.

Keywords: zoonotic, reservoir, rats, bats, leptospirosis, Japanese Encephalitis

\section{Introduction}

Zoonoses are diseases transmitted between vertebrate animals and humans through food (foodborne), air (airborne), and direct contact. The climate and environmental changes have triggered the emergence and re-emergence of zoonoses, of which $\pm 60.3 \%$ and $71.8 \%$ are transmitted by domestic animals and wild animals, respectively (World Health Organization, 2018).

Indonesia is an archipelago country biogeographically located between two animal distribution regions in the world, namely the Orientalis and Australia (Kirnowardoyo, 1991). It puts Indonesia possessing a high number and diversity of wildlife species distributed in various types of habitats and ecosystems, which in turn also affect the 
distribution of vectors and reservoirs of diseases (Simpson, 1977).

Rats and bats are small mammals, which play an important role in many zoonotic infections. In Indonesia, a total of 153 species of genera identified belongs to the subfamily Murinae (rats). The previous studies reported that rats are believed as important zoonotic reservoirs for leptospirosis, hantavirus, typhus scrub, murine typhus, spotted fever group rickettsia, plague, schistosomiasis, rabies, and several other diseases in Indonesia (Ibrahim, 2005).

Since 1320 BC, rats are known as reservoirs of various diseases, 31 of which are caused by worms, 28 by viruses, 26 by bacteria, 14 by protozoa, and eight by rickettsias (Ristiyanto et al., 2014). One of the important rodent-borne diseases is leptospirosis caused by the pathogenic bacteria of the genus Leptospira. Rodents could carry and shed the Leptospira to the environment during urine excretion. Humans can be infected through direct or indirect contact with the urine of infected animals or Leptospira-contaminated water and soil. These bacteria could enter the human body through abraded skins or mucous membranes. Commonly, the disease is spread by domestic rats (Khariri, 2019).

Besides, Indonesia also has more than 200 species of bats ( $21 \%$ of the total species in the world). They belong to nine families, including Pteropodidae, Megadermatidae, Nycteridae, Vespertilionidae, Rhinolophidae, Hipposideridae, Emballonuridae, Rhinopomatidae, and Molossidae (Suyanto, 2001b). Some species are known as potential reservoirs for rabies, severe acute respiratory syndrome (SARS), Marburg virus infection, Nipah virus, Hendra virus, and Japanese Encephalitis (JE) (Suyanto, 2001b; Winoto, Graham, Nurisa, \& Hartati, 1995). For instance, bats from the genus Pteropus have been reported as reservoirs of the Nipah virus in Sumatra (Sendow et al., 2013). Changes in the environment and deforestation trigger the transmission of the viruses from bats to humans (Kardena, I; Sukada, I; Abiyoga, P; Hartawan, D; Diamita, I; Robertson, 2014). A study in West Kalimantan demonstrated that bats also play a significant role in the transmission of the JE virus (JEV) in Kayanhilir and Kayanhulu Districts (Winoto et al., 1995). Further, a study in Tangerang, Banten Province showed that contact with bats or eating bat-leftover bites should be avoided to prevent zoonotic transmission from bats to humans (Wijayanti et al., 2016).

Even though some pieces of evidence have shown that rats and bats play an important role in carrying and transmitting the pathogens, however, the information regarding their potential as reservoirs of Leptospira and JEV in Southeast Sulawesi remains unknown. This study aimed to provide recent epidemiological data from a survey of the presence of Leptospira spp and JEV in rats and bats, particularly in Muna Regency.

\section{Method}

This study was part of the Rikhus Vektora Project (Riset Khusus Vektora) conducted in 2016, focusing on the survey on vectors and reservoirs. A cross-sectional survey was carried out in three districts located in Muna Regency, i.e. Kabawo, Batalaiworu, and Katobu Districts (Figure 1) in August 2016.

\subsection{Study Sites}

Muna Regency is located on Muna Island which is a separate land from Sulawesi Island (Wikipedia, 2020b). Muna is an island in the Southeast Sulawesi province of Indonesia with an area of $3,341.5 \mathrm{~km}^{2}$. It is located just southeast of the island of Sulawesi. Geographical conditions that are separated from the mainland of Sulawesi Island can cause a variety of fauna species that are interesting to study. Aside from that, this location still has a large forest area (Wikipedia, 2020a).

Bats and rats were caught in six ecosystems across the three districts. The six ecosystems were forest near the settlement (FNS, the site I), forest distant from the settlement (FDS, the site II), non-forest near to the settlement (NFNS, the site III), non-forest distant from the settlement (NFDS, the site IV), coast near the settlement (CNS, the site $\mathrm{V}$ ) and coast distant from the settlement (CDS, the site VI).

Study sites were located in six ecosystems that were forest near the settlement (FNS: latitude -5.007" and longitude 122.430"; elevation $70 \mathrm{~m}$ above sea level), forest distant from the settlement (FDS: -5.007" and 122.446"; $79 \mathrm{~m}$ ), non-forest near to the settlement (NFNS: -4.826" and 122.719" with elevation $93 \mathrm{~m}$ ), non-forest distant from the settlement (NFDS: -4.833" and 122.709"; $113 \mathrm{~m}$ ), coast near the settlement (CNS: -4.805" and 122.721"; $69 \mathrm{~m}$ ) and coast distant from the settlement (CDS: -5.032" and 122.389"; $68 \mathrm{~m}$. Muna regency has a 205.769 ha wide area. Muna Regency has a tropical climate like most regions in Indonesia, with an average temperature of around 26$30^{\circ} \mathrm{C}$. Likewise with the seasons, Muna Regency has two seasons, namely the rainy season and the dry season. 


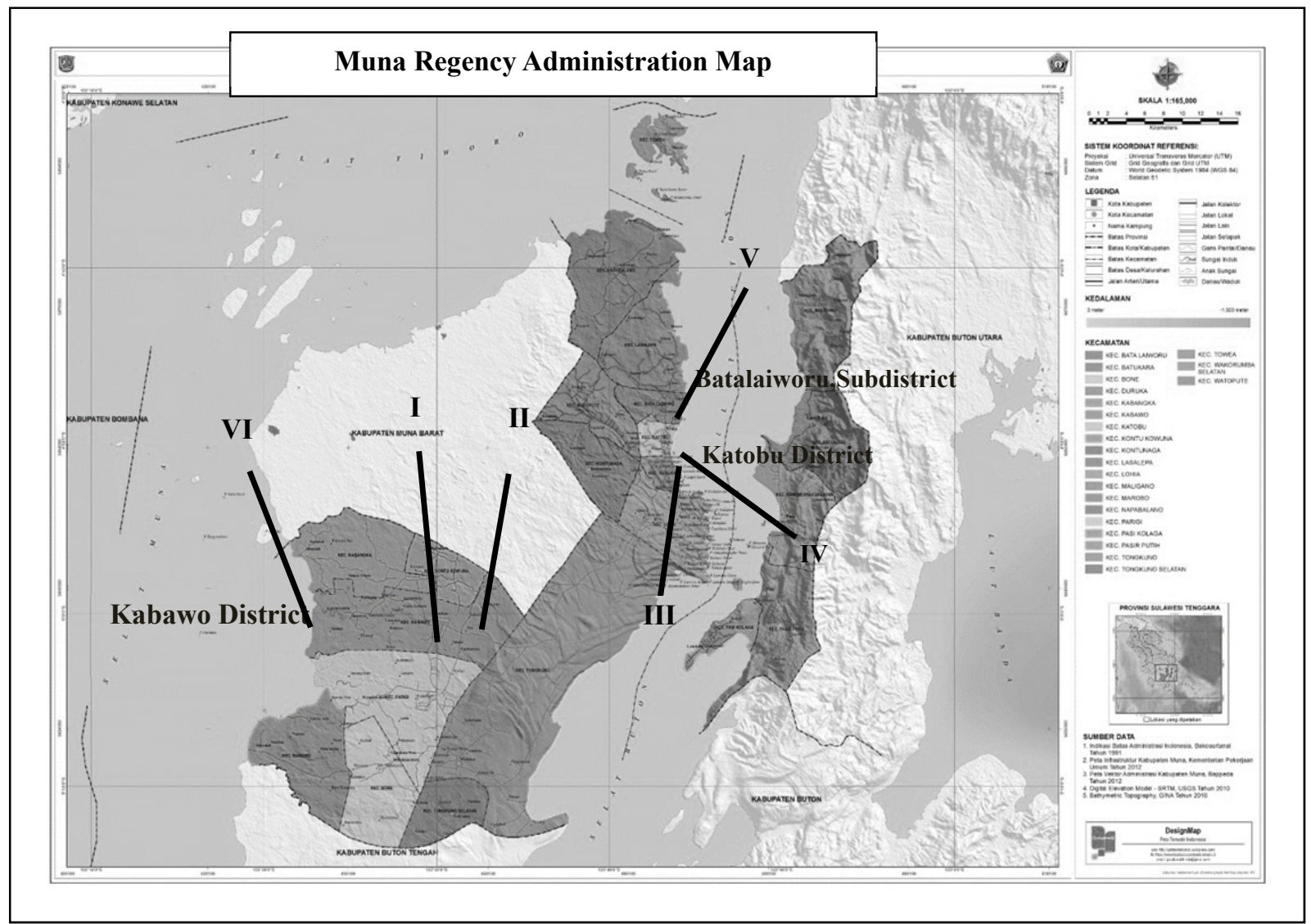

Figure 1. The map of trap in six location: I (FNS) = Forest Near Settlement; II (FDS) = Forest Distant Settlement; III $($ NFNS $)=$ Non-Forest Near Settlement; IV $($ NFDS $)=$ Non-Forest Distant Settlement; V $(C N S)=$ Coast Near Settlement; VI $(\mathrm{CDS})=$ Coast Distant Settlement

\subsection{Data Collection}

All steps of data collection followed the guideline of the survey on vectors and reservoirs collection in the field published by "Riset Khusus Vektora" (B2P2VRP, 2015). Traps were placed in the six predefined types of ecosystems. In each ecosystem, rats were collected during three consecutive days using 100 single live traps sized $12-\mathrm{cm} \times 12-\mathrm{cm} \times 28-\mathrm{cm}$. Roasted coconut was applied as baits. The traps were prepared at 4 PM, placed both inside and outside the house, and they were taken the next morning. The caught rats were put in calico bags and brought to the field laboratory for sample processing and identification. The sample processing involved blood taking through the heart. After that, blood was centrifuged to obtain serum for serological examination. All the rats' kidneys were also collected for molecular examination.

Meanwhile, bats were caught using mist nets and hand nets in one night in each ecosystem. Mist nets were prepared at 4 to $5 \mathrm{PM}$, then the caught bats were collected every hour from 7 to $10 \mathrm{PM}$. Besides, the bats were also collected at $6 \mathrm{AM}$ the next morning.

\subsection{Species Identification}

The rats were identified based on morphological and morphometric characteristics (B2P2VRP, 2017), including the color and hair type, tail color, and scales and hair on the tail. While the latter, weight, total length, tail length, back foot length, ear length, skull length and the number of nipples in female rats were measured or counted. Rat species identification were validated by an expert in the Reservoir Reference Laboratory of the Center for Research and Development of Disease Vectors and Reservoirs (B2P2VRP) using Sulawesi rats key identification from various references (Aplin K.P et al., 2003; Corbet \& Hill, 1992; G. Musser, 2014; G. G. Musser \& Durden, 2014)

The bats identification was based on the morphometric characteristics. Body length was measured from the tip of the nose to the anal canal, the length forearm was measured from the base of the radius bone to the outer elbow. The length of hind foot was measured from the heel to the tip of the longest toe. Ear length was measured from the 
base or base to the tip of the ear the furthest. The tragus length and antitragus length were measured from the base the base to the inner edge where the tragus / antitragus attaches to the head up to ends. Calf length (bet) was measured from knee to ankle. The tail length was measured from the base of the tailbone to the end of the tail. Identification activity refers in the manual (B2P2VRP Salatiga, 2016).

\subsection{Serological and Molecular Detection}

Serological and molecular examinations were performed at the Bacteriology Laboratory, B2P2VRP, Salatiga, Central Java. The serological examination was carried out using the Microscopic Agglutination Test (MAT) 32 with 15 serovars (Bangkinang, Canicola, Grippotyphosa, Icterohaemorragiae, Pyrogenes, Hardjo, Hebdomadis, Pomona, Djasiman, Robinsoni, Bataviae, Mini, Sarmin, Manhao, and Rama). The results will be considered as positive if the titer is $\geq 1: 20$ (Villanueva et al., 2010).

Molecular examination using the polymerase chain reaction (PCR) was performed on the kidneys. The DNA isolation was carried out according to the PureLink Genomic DNA Mini Kit protocol from Invitrogen (Cat. No. K182001) and the target of DNA fragments was amplified using reagent Go Taq ${ }^{\circledR}$ Green Master Mix (Promega, Cat. \# M7122) with primer LipL32 (forward: 5'-ATCTCCGTTGCACTCTTTGC-3'; reverse: 5'-ACCATCATCATCATCGTCCA-3'). The thermal cycler machine was run with a denaturation temperature program of $95{ }^{\circ} \mathrm{C}$ for 5 minutes, amplification of 35 cycles at $94{ }^{\circ} \mathrm{C}$ for 30 seconds, $58{ }^{\circ} \mathrm{C}$ for 30 seconds (annealing), and $72{ }^{\circ} \mathrm{C}$ for 1 minute (extension), and then final extension at $72{ }^{\circ} \mathrm{C}$ for 7 minutes. The PCR products were visualized in agarose gel 2\%. The LipL32 gene would form a DNA band-sized 474 bp (Ahmed et al., 2006).

Molecular examination of JE in bats using Reverse Transcription PCR (RT-PCR) was performed on blood sera. The RNA isolation was carried out according to the QIAamp Viral RNA Mini Kit protocol from Qiagen (Hilden, Germany). The results of the RNA isolation were tested using one-step RT-PCR on NS3 gene using the consensus primers FP (5'-AGA GCG GGG AAA AAG GTC AT-3') and RP (5'-TTT CAC GCT CTT TCT ACA GT-3') (Santhosh et al., 2007). The thermal cycler machine was run with a reverse transcription at $50{ }^{\circ} \mathrm{C}$ for 30 minutes, hot start at $94{ }^{\circ} \mathrm{C}$ for 2 minutes, amplification of 40 cycles at $94{ }^{\circ} \mathrm{C}$ for 15 seconds (denaturation), $55{ }^{\circ} \mathrm{C}$ for 30 seconds (annealing), and $68{ }^{\circ} \mathrm{C}$ for 1 minute (extension), and then final extension at $72{ }^{\circ} \mathrm{C}$ for 5 minutes. The primers corresponded to a PCR product of 162 bp (Garjito et al., 2019).

\subsection{Statistical Analysis}

Descriptive analyses were carried out to describe the frequency and proportion of identified rats and bats species caught during the survey. Chi-square analysis was performed to determine the association between ecosystem types and the species of rats and bats found. All statistical analyses were carried out using SPSS 17 Programme (IBM Corp., Armonk, NY, USA).

\section{Results}

\subsection{Rodents Distribution}

The species distribution of rats in each ecosystem spread in Muna Regency during the survey was significantly different $(P<0.001)$ (Table 1). A total of 137 rats was successfully caught and classified into two genera consisting of seven species. The most abundant species was $R$. tanezumi $(\mathrm{n}=66 ; 48.2 \%)$, followed by $R$. exulans $(\mathrm{n}=18$; $13.1 \%)$. In addition, an endemic species of Sulawesi Island, $R$. hoffmanni was also found in this study ( $\mathrm{n}=12$; $8.8 \%)$. The results showed a significant relationship between the species of the caught rats and the type of ecosystem $(P$-value $<0.001)$. 
Table 1. Distribution of rat species caught in six different ecosystems in Muna Regency, Southeast Sulawesi, 2016

\begin{tabular}{|c|c|c|c|c|c|c|c|c|c|c|c|c|c|c|c|}
\hline \multirow{2}{*}{ Species } & \multicolumn{2}{|c|}{ FNS } & \multicolumn{2}{|c|}{ FDS } & \multicolumn{2}{|c|}{ NFNS } & \multicolumn{2}{|c|}{ NFDS } & \multicolumn{2}{|c|}{ CNS } & \multicolumn{2}{|c|}{ CDS } & \multicolumn{2}{|c|}{ Total } & \multirow{2}{*}{$p$-value } \\
\hline & $\mathrm{N}$ & $\%$ & $\mathrm{~N}$ & $\%$ & $\mathrm{~N}$ & $\%$ & $\mathrm{~N}$ & $\%$ & $\mathrm{~N}$ & $\%$ & $\mathrm{~N}$ & $\%$ & $\mathrm{~N}$ & $\%$ & \\
\hline Mus sp, & 0 & 0.0 & 0 & 0.0 & 0 & 0.0 & 0 & 0.0 & 0 & 0.0 & 2 & 4.8 & 2 & 1.5 & 0.000 \\
\hline $\begin{array}{l}\text { Rattus } \\
\text { exulans }\end{array}$ & 4 & 22.2 & 3 & 42.9 & 0 & 0.0 & 0 & 0.0 & 4 & 13.3 & 7 & 16.7 & 18 & 13.1 & \\
\hline $\begin{array}{l}\text { Rattus } \\
\text { hoffmanni }\end{array}$ & 2 & 11.1 & 1 & 14.3 & 0 & 0.0 & 0 & 0.0 & 3 & 10.0 & 6 & 14.3 & 12 & 8.8 & \\
\hline $\begin{array}{l}\text { Rattus } \\
\text { argentiventer }\end{array}$ & 0 & 0.0 & 0 & 0.0 & 3 & 12.5 & 2 & 12.5 & 0 & 0.0 & 9 & 21.4 & 14 & 10.2 & \\
\hline $\begin{array}{l}\text { Rattus } \\
\text { nitidus }\end{array}$ & 0 & 0.0 & 0 & 0.0 & 11 & 45.8 & 0 & 0.0 & 2 & 6.7 & 0 & 0.0 & 13 & 9.5 & \\
\hline $\begin{array}{l}\text { Rattus } \\
\text { norvegicus }\end{array}$ & 0 & 0.0 & 0 & 0.0 & 6 & 25.0 & 0 & 0.0 & 6 & 20.0 & 0 & 0.0 & 12 & 8.8 & \\
\hline $\begin{array}{l}\text { Rattus } \\
\text { tanezumi }\end{array}$ & 12 & 66.7 & 3 & 42.9 & 4 & 16.7 & 14 & 87.5 & 15 & 50.0 & 18 & 42.9 & 66 & 48.2 & \\
\hline Total & 18 & 100.0 & 7 & 100.0 & 24 & 100.0 & 16 & 100.0 & 30 & 100.0 & 42 & 100.0 & 137 & 100.0 & \\
\hline
\end{tabular}

Comments: FNS, Forest Near Settlement; FDS, Forest Distant Settlement; NFNS, Non-Forest Near Settlement; NFDS, Non-Forest Distant Settlement; CNS, Coast Near Settlement; CDS, Coast Distant Settlement.

\subsection{Detection of Leptospira in Rodents}

Based on the PCR examination, the overall prevalence of Leptospira in rats was $29.2 \%$. Six out of seven species were confirmed positive for leptospirosis using PCR. Of which, the highest prevalence of Leptospira spp was found in $R$. argentiventer $(\mathrm{n}=7 / 14 ; 50 \%)$ followed by $R$. tanezumi $(\mathrm{n}=24 / 66 ; 36.4 \%)$. Whereas based on MAT, only three species were found to be positive Leptospira and the overall prevalence was $9.5 \%$. Based on the Chi-Square analysis, there was a correlation between species with the laboratory test results (using the PCR method) with a $P$-value $<0.05$. The rats confirmed positive from Leptospira were detected in five ecosystems, i.e. FNS, FDS, NFNS, NFDS and CDS. None positive rat was found in the CNS ecosystem.

Table 2. Leptospirosis test results on rat species in Muna Regency, Southeast Sulawesi, 2016

\begin{tabular}{|c|c|c|c|c|c|c|}
\hline \multirow{3}{*}{ Species } & \multirow{3}{*}{$\begin{array}{l}\text { No. of } \\
\text { rats }\end{array}$} & \multicolumn{4}{|c|}{ Method of Leptospirosis Tests } & \multirow{3}{*}{$\begin{array}{c}\text { Comments } \\
\text { Serovar }\end{array}$} \\
\hline & & \multicolumn{2}{|l|}{ PCR } & \multicolumn{2}{|l|}{ MAT } & \\
\hline & & Positive, $(\%)$ & p-value & Positive, (\%) & p-value & \\
\hline Mus sp, & 2 & $0(0.0)$ & & $0(0.0)$ & & \\
\hline Rattus exulans & 18 & $1(5.6)$ & & $0(0.0)$ & & \\
\hline Rattus hoffmanni & 12 & $3(25.0)$ & & $1(8.3)$ & & Ict 80, Dja 20 \\
\hline Rattus argentiventer & 14 & $7(50.0)$ & & $0(0.0)$ & & \\
\hline Rattus nitidus & 13 & $4(30.8)$ & 0.045 & $1(7.7)$ & 0.182 & Gri 20 \\
\hline Rattus norvegicus & 12 & $1(8.3)$ & & $0(0.0)$ & & \\
\hline Rattus tanezumi & 66 & $24(36.4)$ & & $11(16.7)$ & & $\begin{array}{c}\text { Bat } 80, \text { Dja } 20, \text { Dja } 40, \text { Heb } \\
20 \text {, Ict } 20 \text {, Ict } 40 \text {, Pom } 40\end{array}$ \\
\hline Total & 137 & $40(29.2)$ & & $13(9.5)$ & & \\
\hline
\end{tabular}

Comments: $\mathrm{PCR}=$ Polymerase Chain Reaction, $\mathrm{MAT}=$ Microscopic Agglutination Test, Ict $=$ Icterohaemorragiae, $\mathrm{Dja}=$ Djasiman, Gri $=$ Grippotyphosa, Bat $=$ Bataviae, $\mathrm{Heb}=$ Hebdomadis, Pom $=$ Pomona. 
Table 3. Rats that Leptospirosis confirmed using MAT in six different ecosystems in Muna Regency, Southeast Sulawesi, 2016

\begin{tabular}{llc}
\hline Ecosystem & Species & Type of serovar \\
\hline Forest Near Settlement & Rattus hoffmanni & Ict 80 and Dja 20 \\
Forest Distant Settlement & R.tanezumi & Bat 80 \\
Non Forest Near Settlement & R.nitidus & Gri 20 \\
& R.tanezumi & Ict 20 and Dja 20 \\
Non Forest Distant Settlement & R.tanezumi & Gri 20, Heb 20, Ict 20 and Dja \\
Coastal Near Settlement & & 20 \\
Coastal Distant Settlement & R.tanezumi & Pom 40 \\
\hline
\end{tabular}

Table 3 showed that Rattus tanezumi was the most confirmed Leptospira positive species, with various types of serovar. In term of ecosystem, based on MAT method, $R$. hoffmanni captured in the FNS was confirmed Leptospira positive with Ict 80 and Dja 20 serovars. In addition, R. tanezumi and $R$. nitidus caught in the FDS and NFNS ecosystems were also confirmed Leptospira positive with Bat 80 and Gri 20 serovars, respectively. The PCR results demonstrated that $R$. tanezumi caught in the FNS, FDS, and NFNS ecosystems were also confirmed positive from Leptospira infection. All rats trapped in the CNS ecosystem were free from Leptospira infection either based on MAT or PCR examinations.

\subsection{Bats Distribution}

The distribution of bat species caught in the present study can be seen in Table 4 . There were 14 species of 10 genera rat trapped in Muna regency. The most captured bats were Dobsonia viridis $(\mathrm{n}=19)$ (Figure 2), followed by Rousettus celebensis $(\mathrm{n}=18)$ and Styloctenium wallacei $(\mathrm{n}=14$, endemic spesies of Sulawesi). The endemic bat species trapped were Dobsonia exoleta, D. viridis, Eonyteris spelaea, Nyctimene cephalotes, Pteropus alecto, Rousettus celebensis, and Styloctenium wallacei (Figure 3). Dobsonia viridis and Rousettus celebensis were the most caught species (20.93\%). Dobsonia viridis was most commonly found in the NFNS ecosystems and trapped in gardens and yards where papaya trees grew up. Whereas Rousettus celebensis was found in NFDS ecosystem and trapped in gardens and CNS ecosystem and trapped in the yard with papaya and guava vegetation. The second highest percentage was of Styloctenium wallacei (16.78\%). Like Dobsonia viridis, this species was often found in the Non-Forest Near Settlement ecosystem.
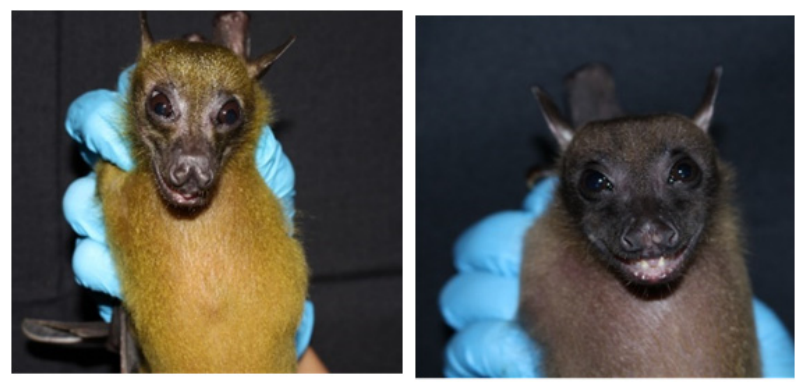

Figure 2. Dobsonia viridis and D.exoleta
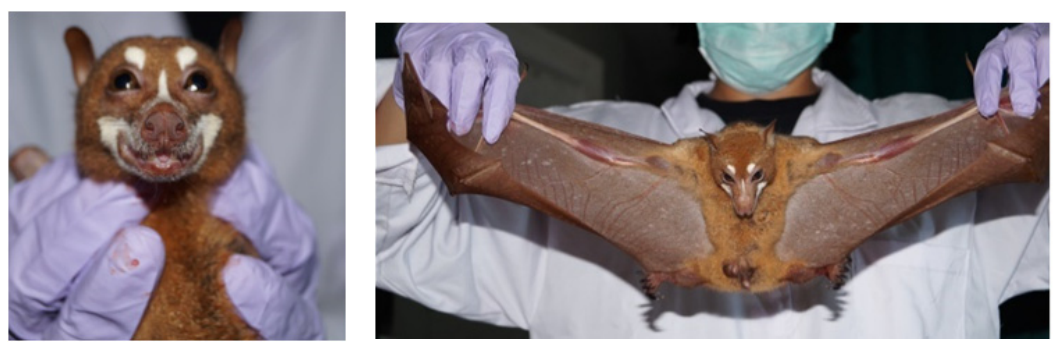

Figure 3. Styloctenium wallacei (Sulawesi stripe-faced fruit bat) 
Table 4. Distribution of caught bats in six different ecosystems in Muna Regency, Southeast Sulawesi, 2016

\begin{tabular}{|c|c|c|c|c|c|c|c|c|c|c|c|c|c|c|c|}
\hline \multirow{2}{*}{ Species } & \multicolumn{2}{|c|}{ FNS } & \multicolumn{2}{|c|}{ FDS } & \multicolumn{2}{|c|}{ NFNS } & \multicolumn{2}{|c|}{ NFDS } & \multicolumn{2}{|c|}{ CNS } & \multicolumn{2}{|c|}{ CDS } & \multicolumn{2}{|c|}{ Total } & \multirow{2}{*}{ P-value } \\
\hline & $\mathrm{N}$ & $\%$ & $\mathrm{~N}$ & $\%$ & $\mathrm{~N}$ & $\%$ & $\mathrm{~N}$ & $\%$ & $\mathrm{~N}$ & $\%$ & $\mathrm{~N}$ & $\%$ & $\mathrm{~N}$ & $\%$ & \\
\hline $\begin{array}{l}\text { Cynopterus } \\
\text { brachyotis }\end{array}$ & 0 & 0.0 & 1 & 11.1 & 0 & 0.0 & 0 & 0.0 & 5 & 33.3 & 0 & 0 & 6 & 7.0 & \\
\hline $\begin{array}{l}\text { Cynopterus } \\
\text { luzoniensis }\end{array}$ & 0 & 0.0 & 0 & 0.0 & 0 & 0.0 & 0 & 0.0 & 1 & 6.7 & 0 & 0.0 & 1 & 1.2 & \\
\hline $\begin{array}{l}\text { Cynopterus } \\
\text { minutus }\end{array}$ & 0 & 0.0 & 0 & 0.0 & 0 & 0.0 & 0 & 0.0 & 0 & 0.0 & 1 & 11.1 & 1 & 1.2 & \\
\hline Dobsonia exoleta & 0 & 0.0 & 0 & 0.0 & 0 & 0.0 & 2 & 11.1 & 0 & 0.0 & 0 & 0.0 & 2 & 2.3 & \\
\hline Dobsonia viridis & 1 & 9.1 & 1 & 11.1 & 9 & 37.5 & 5 & 27.8 & 3 & 20.0 & 0 & 0.0 & 19 & 22.1 & \\
\hline $\begin{array}{l}\text { Eonycteris } \\
\text { spelaea }\end{array}$ & 0 & 0.0 & 0 & 0.0 & 2 & 8.3 & 1 & 5.6 & 0 & 0.0 & 0 & 0.0 & 3 & 3.5 & \\
\hline $\begin{array}{l}\text { Falsistrellus } \\
\text { petersi }\end{array}$ & 0 & 0.0 & 1 & 11.1 & 0 & 0.0 & 0 & 0.0 & 0 & 0.0 & 0 & 0.0 & 1 & 1.2 & \\
\hline $\begin{array}{l}\text { Kerivoula } \\
\text { hardwickii }\end{array}$ & 1 & 9.1 & 1 & 11.1 & 0 & 0.0 & 0 & 0.0 & 0 & 0.0 & 0 & 0.0 & 2 & 2.3 & 0.000 \\
\hline $\begin{array}{l}\text { Macroglossus } \\
\text { minimus }\end{array}$ & 1 & 9.1 & 0 & 0.0 & 0 & 0.0 & 0 & 0.0 & 0 & 0.0 & 0 & 0.0 & 1 & 1.2 & \\
\hline $\begin{array}{l}\text { Nyctimene } \\
\text { cephalotes }\end{array}$ & 4 & 36.4 & 1 & 11.1 & 0 & 0.0 & 0 & 0.0 & 0 & 0.0 & 0 & 0.0 & 5 & 5.8 & \\
\hline Pteropus alecto & 0 & 0.0 & 0 & 0.0 & 0 & 0.0 & 2 & 11.1 & 0 & 0.0 & 0 & 0.0 & 2 & 2.3 & \\
\hline $\begin{array}{l}\text { Rousettus } \\
\text { amplexicaudatus }\end{array}$ & 0 & 0.0 & 1 & 11.1 & 4 & 16.7 & 3 & 16.7 & 1 & 6.7 & 2 & 22.2 & 11 & 12.8 & \\
\hline $\begin{array}{l}\text { Rousettus } \\
\text { celebensis }\end{array}$ & 1 & 9.1 & 1 & 11.1 & 3 & 12.5 & 5 & 27.8 & 5 & 33.3 & 3 & 33.3 & 18 & 20.9 & \\
\hline $\begin{array}{l}\text { Styloctenium } \\
\text { wallacei }\end{array}$ & 3 & 27.3 & 2 & 22.2 & 6 & 25.0 & 0 & 0.0 & 0 & 0.0 & 3 & 33.3 & 14 & 16.3 & \\
\hline Total & 11 & 100.0 & 9 & 100.0 & 24 & 100.0 & 18 & 100.0 & 15 & 100.0 & 9 & 100.0 & 86 & 100.0 & \\
\hline
\end{tabular}

Comments: FNS $=$ Forest Near Settlement, FDS $=$ Forest Distant Settlement, NFNS $=$ Non-Forest Near Settlement, NFDS $=$ Non-Forest Distant Settlement, CNS $=$ Coast Near Settlement CDS $=$ Coast Distant Settlement.

The statistical analysis showed that there was a correlation between the difference in bat species and that in ecosystems. Twelve species collected from Muna Regency are commonly found in the island of Sulawesi. From this study in Muna Regency, Sulawesi Tenggara Province, 12 species from 10 genera were found. An endemic species in the island of Sulawasi, namely Styloctenium wallace, was found. Cynopterus brachyotis, Pteropus alecto, Rousettus amplexicaudatus, Eonycteris spelaea, Macroglossus minimus, and Kerivoula hardwickii species were found in almost all regions of Indonesia. Based on the results of the study, there was a bat species commonly found on Sulawesi Island, but not found on Java and Sumatra, namely Dobsonia viridis.

Dobsonia viridis and Rousettus celebensis were the most caught species (20.93\%). Dobsonia viridis was most commonly found in the NFNS ecosystems and trapped in gardens and yards on which papaya trees grew up. Whereas $R$. celebensis was found in NFDS ecosystem and trapped in gardens and the CNS ecosystem and trapped in the yard with papaya and guava vegetation. The second highest percentage was of $S$. wallacei $(16.78 \%)$.

\subsection{Detection of JEV in Bats}

The result of confirmed positive rats from the JE can be seen in Table 5. It revealed that three species of rat was confirmed positive from JE, i.e. D. viridis, R. celebensis, and $S$. wallacei. They were known as the endemic species in Sulawesi Island. 
Table 5. The species of bats caught in Muna Regency, Southeast Sulawesi confirmed positive for the JE virus.

\begin{tabular}{llcc}
\hline \multirow{2}{*}{ Species } & No. of bats & \multicolumn{2}{c}{ JE test results } \\
\cline { 3 - 4 } & & No. of positive, (\%) & No. of negative, $(\%)$ \\
\hline Cynopterus brachyotis & 2 & $0(0.0)$ & $6(18.2)$ \\
Dobsonia viridis & 7 & $1(33.3)$ & $1(3.0)$ \\
Falsistrellus petersi & 1 & $0(0.0)$ & $1(3.0)$ \\
Kerivoula hardwickii & 1 & $0(0.0)$ & $1(3.0)$ \\
Macroglossus minimus & 1 & $0(0.0)$ & $2(6.1)$ \\
Nyctimene cephalotes & 2 & $0(0.0)$ & $2(6.1)$ \\
Pteropus alecto & 2 & $0(0.0)$ & $6(18.2)$ \\
Rousettus amplexicaudatus & 6 & $0(0.0)$ & $8(24.2)$ \\
Rousettus celebensis & 9 & $1(33.3)$ & $4(12.1)$ \\
Styloctenium wallacei & 5 & $1(33.3)$ & $33(100)$ \\
\hline Total & 36 & $3(100)$ & \\
\hline
\end{tabular}

\section{Discussion}

In this study, the presence of Leptospira in rats and JEV in bats was successfully detected in some ecosystems during the survey in Muna Regency, Southeast Sulawesi. These findings highlighted the potential of such animals as reservoirs, which could play important role in maintaining disease transmission such as leptospirosis and JE in the region. The current study, to the best of our knowledge, is the first study that provides epidemiological evidence of the presence of Leptospira and JEV in rats and bats, respectively, in Southeast Sulawesi.

The dominance of Rattus tanezumi's dominance is referred to several factors, one of which is the habitat of the rat. $R$. tanezumi has wide habitats, from primary forests, secondary forests, tropical rain forests, villages, plantations, office buildings, to residential areas, or at an altitude of 0-2000 meters above sea level (Maharadatunkamsi, 2011). Their acclimation ability to the various environment is one of the factors why the rats can spread widely and rapidly, leading it to be known as cosmopolitan animals (occupying almost all habitats). In this study, R. tanezumi was predominant in residential/home locations, for example in the Forest Near Settlement (FNS), Non-Forest Distant Settlement (NFDS), Coast Near Settlement (CNS), and Coast Distant Settlement (CDS) ecosystems. The results were supported by the theory and various studies about the habitat of $R$. tanezumi. In the Non-Forest Near Settlement ecosystem, the dominance of $R$. tanezumi was defeated by $R$. nitidus.

The second dominance was shown by $R$. exulans, with a percentage of $13.14 \%$. Its habitat includes fields, gardens near settlements, plantations, and forests (Ristiyanto et al., 2014; Suyanto, 2001a). According to the activities, the rat prefers active outside houses (Ibrahim, 2005; Mulyono et al., 2016). This species can live at 0-2000 masl, like $R$. tanezumi. In addition, the rat is also categorized as commensal and a high destructive rodent (Farida et al., 2006). During the survey, R. exulans was found in the Forest Distant Settlement (FDS, primary forests), Forest Near settlement (FNS), Coast Near Settlement (CNS), and Coast Distant Settlement (CDS) ecosystems. The Forest Distant Settlement (FDS) ecosystem in Muna Regency was recently opened by the community to generate large gardens. This is in line with the theory that the existence of $R$. exulans, which is a commensal type in primary forest areas, is one indication of habitat destruction in an area. $R$. exulans activities are usually in a residential area, plantation, and rice fields. The existence of these rats in primary forests is possible, following humans' activities (Maharadatunkamsi, 2011).

In this research, R. exulans were found to dominate in the Coast Distant Settlement (CDS) ecosystem, around the ponds. Rattus exulans were also caught in the forest ecosystems, both near and far from settlements showing the characteristic for eastern Indonesia, by the presence of bright dark bicolor tails in the ventral-dorsal but not too contrast (G. G. Musser \& Durden, 2014). This bicolor tail resembles the tail of Maxomys mucchenbroeckii, but the size is thin.

Rattus argentiventer was the third of the total rats collected. The characteristic of the species is yellowish-brown hair and gray belly hair with white edges. The habitat of $R$. argentiventer includes paddy fields, fields, and pastures, 
where they get their favorite food in the form of rice, corn, or grass. They make nests in holes in the ground, under rocks, or in wood scraps (Suyanto, 2001a). In this study, R. argentiventer was the predominant species found in the Coast Distant Settlement (CDS) ecosystems, in the area of ponds with forest plants that make up the coastal ecosystem. The types of vegetations found were lontar (Borassus flabellifer), thistle (Calotrophis gigantea), ketapang (Terminalia cattapa), tallowwood, and some plants planted by farmers, such as chili, papaya, banana, and watermelon. The existence of watermelon in the field was believed as the source of feed for rats.

Rattus nitidus, R. norvegicus, R. hoffmanni dan Mus sp. were found in a few numbers indicating that their territory were not too broad. The characteristic of $R$. nitidus was similar to R.norvegicus, but $R$. nitidus has a ventral-dorsal bicolor tail although it is not too contrasting like the tail of the genus Bunomys (G. Musser, 2014). Even though rats found in Muna Regency were not endemic in Sulawesi and were commonly found in other areas, these results provided new information about the distribution of rats in that regency. The highest diversity of rat species was found in the Coast Distant Settlement (CDS) ecosystem. There were five of the seven species were collected at that location. The location of the CDS point in Muna Regency was an area with shrimp ponds with mangrove vegetation. The existence of these ponds was inferred as the source of food for rats from both natural areas and settlements.

The test for leptospirosis in the laboratory showed that the most vulnerable species to be exposed to leptospirosis was $R$. tanezumi or domestic rats. Several studies have also shown that cases of leptospirosis were found in rats near residential areas (Ardanto et al., 2018; Farida et al., 2006; Ikawati et al., 2013b). Human activities in the forest, such as collecting woods, hunting, and ecotourism activities could increase the risk of the transmission of leptospirosis to humans. Humans are infected through contact with water contaminated with the urine of infected animals or direct contact with reservoir animals. In the case of transmission in forests, humans might be infected by leptospirosis through standing water or polluted rivers in the forest or direct contact with infected animals, especially when hunting rats. Unfortunately, the endemic rats are slaughtered and sold in traditional markets in Sulawesi. Direct contact with rats, including their preparation before being cooked could be a route of transmission of the disease.

The rats detected positive for leptospirosis in Muna Regency were all from the genus Rattus, namely $R$. tanezumi, $R$. argentiventer, $R$. nitidus, $R$. hoffmani, $R$. norvegicus, and $R$. exulans. The types of these rats belonged to the group of those having habitats in settlements or Non-Forest Near Settlement. The geographical environment of those sites could increase the potential of leptospirosis transmission associated with human activities near the rats' habitats. The domestic rats (R. tanezumi) caught at the house could be an indicator of the level of hygienic and sanitary house environment. The individual pattern of living of rats was influenced by the comparison of the differences observed in the histological and the quantitative histochemical activities in these mammalian species (Adeniyi et al., 2012).

The potential of rats as reservoirs of leptospirosis is generally dominated by commensal species. Based on the laboratory analyses that $R$. tanezumi or domestic rats were the most species with confirmed positive from leptospirosis(Ikawati et al., 2013; Ristiyanto et al., 2006; Ristiyanto et al., 2015; Sunaryo \& Ningsih, 2014).. Rats trapped near houses potentially act as leptospirosis reservoirs. Rats living in natural habitats or being rarely in contact with human activities might have a low risk to be reservoirs of leptospirosis (Riyaningsih et al., 2012). Rats circulated in the habitats close to water tend to be potentially infected by Leptospira. For example, R. norvegicus, which primarily lived in sewers possess a high risk to be infected by Leptospira sp. Female rats can vertically transmit Leptospira spp. to the kids in the same location (Ramadhani \& Yunianto, 2010).

The information about Leptospira positive rats in Muna Regency has never been reported. This current study is the first report of the potency of rats distributed in Muna Regency as a reservoir for leptospirosis. The previous studies conducted in South Sulawesi Province also showed new records of several endemic species of rats in Sulawesi with positive leptospirosis. The results indicated that various endemic rats such as $R$. marmosurus, $R$. hoffmanni, $B$. chrysocomus, B. andrewsi and B. coelestis were infected with leptospirosis (Ardanto et al., 2018).

These findings provide preliminary information for the management of the infectious disease program in the local health office to increase awareness of leptospirosis. Residents who are active in areas close to rat habitat are expected to be more aware by wearing Personal Protective Equipment (PPE) and maintaining personal hygiene. This information should also increase community self-awareness to keep their house clean, including the environment surrounding the house. People should be adequately informed that domestic rats are the important animal in transmiting Leptospira. It would be a threaten for their health if they do not keep the hygienic and sanitary surrounding the house.

Based on the statistical analysis, the confirmed positive rats from leptospirosis were related to the ecosystem and 
species. This finding was in line with other researchers stating that the diversity of types of rats acted as a reservoir of Leptospira sp. in highland areas was different from lowland areas (Marbawati et al., 2016). Therefore, the efforts to tackle leptospirosis require a specific method (local specific) depending on the type of their habitat. Direct transmission of leptospirosis between rats occurs in various ways. Rats were vertically exposed to the bacteria Leptospira spp. from the parent or were exposed to bacteria in the nest before weaning. After the weaning period, the rat will come out from the nest and then be exposed to a polluted environment and direct contact with other rats. The other animal species are transmitted from Leptospira spp by drinking contaminated water (Narkkul et al., 2020). Rats also can be infected by Leptospira spp through sexual contact after reaching their adulthood (Minter, Diggle, Costa, Childs \& M., 2017). In Thailand, people got the infection of Leptospira from bathing using contaminated water (Hinjoy et al., 2019).

To deal with various diseases transmitted through rats (especially leptospirosis) could be achieved from the knowledge of the bionomic approach. Preventing leptospirosis cannot be conducted individually. The point of controlling leptospirosis relies on environmental- and community-based control, including rat control. A study shows that disseminating knowledge on how to prevent leptospirosis to the community could increase their awareness (Farida et al., 2006). Control measures should be implemented including managing wastes properly, keeping the house clean, and maintaining the hygienic and sanitary of sewage. A study in Kedah proved that the predictive factors will help clinicians to identify severe leptospirosis cases earlier and develop their treatment plans so that the complications and mortality rate from severe leptospirosis can be reduced (Sandhu et al., 2020). Besides rats, in Brazil, Leptospira was found in bovine (65.69\%), equine (20.32\%), and canine (5.64\%) (Polo et al., 2019).

Japanese encephalitis (JE) is a disease caused by a zoonotic virus that causes inflammation of the brain in young humans (5-9 years of age) and is transmitted through mosquitos as the vectors. The primary mosquito vector of JEV is Culex tritaeniorhynchus, although species such as Cx. gelidus, Cx. fuscocephala, and Cx. annulirostris are important secondary or regional vectors (van den Hurk et al., 2009). In Asia and Pacific vector JE is Culex mosquitoes, particularly, $C x$. tritaeniorhynchus and $C x$. vishnui which utilizes rice fields for larval development (van den Hurk et al., 2009; van den Hurk et al., 2019). The existence of JE-related viruses, vectors, and animals probable to be reservoirs in various regions of Indonesia requires vigilance against the possibility of outbreaks of this disease. The presence of JE in humans in Indonesia has been revealed based on clinical symptoms and serological examination. The latest cases of JE in Bali has become hyper-endemic, which was usually sporadic (Sendow \& Bahri, 2005).

Previous data indicated that Cynopterus brachyotis was not found on Sulawesi Island (Suyanto, 2001b). Rousettus celebensis was found in NFDS ecosystem and trapped in gardens and CNS ecosystem and trapped in the yard with papaya and guava vegetation. This is following (Csorba et al., 2003) who stated that $R$. celebensis can be found in a variety of habitat types, such as secondary forests, agricultural areas, and disturbed habitats, while $D$. viridis is a species commonly found in disturbed forests, coconut gardens, and parks (Wiantoro, 2012). The second highest percentage was of $S$. wallacei. Like D. viridis, this species was often found in the Non-Forest Near Settlement ecosystem. It loves forest ecosystems with altitudes up to $1100 \mathrm{~m}$ asl, but it can also be found in disturbed forests (Patterson et al., 2017).

Besides mosquitoes, bats are are also known to be reservoirs of JE causing fatal to human life. Fruit-eating bats reported as reservoirs of JE disease in Indonesia are Rousettus leschenaulti, Cynopterus sp., Eonycteris sp., Myotis sp (Winoto et al., 1995). In the present study, three species were confirmed positive as reservoirs of JE. The three species were $D$. viridis (one positive from one examined), $R$. celebensis, and $S$. wallacei. The three species were found in the Forest Distant Settlement (FDS), Non-Forest Distant Settlement (NFDS), and Coast Distant Settlement (CDS) ecosystem. Interestingly, the three species are only found in Sulawesi Island, but not exist in other islands in Indonesia. The flying ability of bats up to tens kilometers could be a pathway of viral transmission from one region to other regions. The finding of $R$. celebensis and $S$. wallacei as JE reservoirs in Sulawesi Island is a new evidence in Indonesia, so far. Meanwhile, D. viridis has been previously reported as a JE reservoir in Sulawesi Island.

Bats activities in humans' environment to find food is one of the vigilance risks of the transmission of the JE virus. When a bat eats fruit and leaves it, the part bitten by the bat can be a risk factor for the transmission of the JE virus. The presence of livestock such as pigs is also a risk factor for JE transmission. Even though bats distributed in Muna Regency were confirmed positive for JE, however no JE cases have been reported in humans. This finding should be an early warning system for controlling JE virus transmission. The discovery of rats detected positive for leptospirosis and bats confirmed positive for JE in Muna Regency showed that there is a potential for zoonotic disease transmission in the region. 


\section{Conclusion}

Our study demonstrates that rats and bats are a potential reservoir of Leptospira and JEV in Muna Regency, respectively. These animals could be an important potential source of transmission for leptospirosis and JE infections in humans. This evidence highlights the importance of surveillance for leptospirosis and JE in the region. In addition, local health authorities need to manage and promote the strategy of the preventive program in order to mitigate the potential risk of zoonotic infections.

\section{Acknowledgments}

This research was a part of the Rikhus Vektora 2016. The authors would like to thank the Southeast Sulawesi Provincial Health Office and Muna Regency Health Office. We also would like to thank the Rikhus Vektora 2016 Team of Muna Regency for assisting so that the research could be accomplished well.

\section{Shift Contributors}

A.N.W, M.A.N, A.A, and R is the main contributors. "Conceptualization, A.N.W and M.A.N.; methodology, A.N.W.; software, M.A.N.; validation, A.A, R and P.W.D.; formal analysis, M.A.N.; investigation, A.A.; resources, R.; data curation, M.A.N.; writing — original draft preparation, A.N.W and M.A.N.; writing — review and editing, A.N.W, M.A.N, A.A, R, P.W.D and A.H.W. All authors have read and agreed to the published version of the manuscript.",

\section{Competing Interests Statement}

The authors hereby declare that there is no potential conflict of interest in writing this article.

\section{References}

B2P2VRP. (2017). Suplemen Reservoir: Tikus dan Kelelawar Indonesia (2nd ed.). Lembaga Penerbit Badan Penelitian dan Pengembangan Kesehatan.

Adeniyi, T., Tijani, A., Adekomi, D., \& Abayomi, T. (2012). A comparative study of the lateral geniculate body of rat (Rattus norvegicus), bat (Eidolon helvum) and pangolin (Manis tricuspis). Global Journal of Health Science, 4(4), 118-125. https://doi.org/10.5539/gjhs.v4n4p118

Ahmed, N., Manjulata Devi, S., de los Á Valverde, M., Vijayachari, P., Machang'u, R. S., Ellis, W. A., \& Hartskeerl, R. A. (2006). Multilocus sequence typing method for identification and genotypic classification of pathogenic Leptospira species. Annals of Clinical Microbiology and Antimicrobials, 5. https://doi.org/10.1186/1476-0711-5-28

Aplin, K. P., Brown, P. R., Jacob, J., Krebs, C. J., \& Singleton, G. R. (2003). Field methods for rodent studies in Asia and the Indo-Pacific (Issue January). BPA Print Group, Melbourne.

Ardanto, A., Yuliadi, B., Martiningsih, I., Putro, D. B. W., Joharina, A. S., \& Nurwidayati, A. (2018). Leptospirosis pada Tikus Endemis Sulawesi (Rodentia: Muridae) dan Potensi Penularannya Antar Tikus dari Provinsi Sulawesi Selatan. Balaba, 14(2), 135-146. https://doi.org/10.22435/blb.v14i2.196

B2P2VRP. (2015). RISET KHUSUS VEKTOR DAN RESERVOIR PENYAKIT (RIKHUS VEKTORA), Laporan Provinsi Sulawesi Tengah.

B2P2VRP Salatiga. (2016). Laporan Rikhus Vektora Sulawesi Tenggara, 2016.

Corbet, G. B., Gordon B., \& Hill, J. E. (1992). The mammals of the Indomalayan Region : a systematic review. Oxford University Press.

Csorba, G., Ujhelyi, P., \& Thomas, N. (2003). Horseshoe bats of the World (Chiroptera: Rhinolophidae). Alana Books.

Farida, D. H., Ristiyanto, Yuliadi, B., Sukarmo, \& Muhidin. (2006). Distribusi dan Faktor Lingkungan Penularan Leptospirosis di Kabupaten Demak, Jawa Tengah. Vektora, II(2), 126-139.

Garjito, T. A., Prihatin, M. T., Susanti, L., Prastowo, D., Sa'Adah, S. R., Taviv, Y., ... \& Frutos, R. (2019). First evidence of the presence of genotype-1 of Japanese encephalitis virus in Culex gelidus in Indonesia. Parasites and Vectors, 12(1), 10-13. https://doi.org/10.1186/s13071-018-3285-7

Hinjoy, S., Kongyu, S., Doung-Ngern, P., Doungchawee, G., Colombe, S. D., Tsukayama, R., \& Suwancharoen, D. (2019). Environmental and behavioral risk factors for severe leptospirosis in Thailand. Tropical Medicine and Infectious Disease, 4(79), 1-12. https://doi.org/10.3390/tropicalmed4020079

Ibrahim, R. (2005). Penyakit Bersumber Rodensia (Tikus dan Mencit) di Indonesia. Jurnal Ekologi Kesehatan, 
4(3), 308-310.

Ikawati, B., Raharjo, J., \& Astuti, N. T. (2013). Gambaran Epidemiologi Leptospirosis Di Kecamatan Jepara, Kabupaten Jepara, Provinsi Jawa Tengah. Buletin Penelitian Kesehatan, 41(1), 37-44.

Kardena, I., Sukada, I., Abiyoga, P., Hartawan, D., Diamita, I., \& Robertson, I. (2014). Analisa risiko kualitatif nipah virus di indonesia. Buletin Veteriner, BBVet Denpasar, XXVI(84).

Khariri. (2019). Survei keanekaragaman tikus sebagai hewan pembawa bakteri Leptospira di Provinsi Jawa Tengah Survey of mouse diversity as an animal carrying Leptospira bacteria in Central Java Province. Prosiding Seminar Nasional Masyarakat Biodiversity Indonesia, 5, 42-45. https://doi.org/10.13057/psnmbi/m050109

Kirnowardoyo. (1991). Penelitian vektor malaria yang dilakukan oleh institusi kesehatan tahun 1975-1990. Buletin Penelitian Kesehatan, 19(4), 24-32.

Maharadatunkamsi. (2011). Profil Mamalia Kecil Gunung Slamet Jawa Tengah. Jurnal Biologi Indonesia, 7(1), 171-185. https://doi.org/10.14203/jbi.v7i1.3137

Marbawati, D., Ismanto, H., \& Pramestuti, N. (2016). Characteristics of Rats as Reservoirs of Leptospirosis in Beji Village Districtf of Kedung Banteng and Kedung Pring VIillage District of Kemranjen Banyumas, Central Java. Kesmas: National Public Health Journal, 10(1), 35-40.

Minter, A., Diggle, P. J., Costa, F., Childs, J. K. A., \& M., B. (2017). Evidence of multiple intraspecific transmission routes for Leptospira acquisition in Norway rats (Rattus norvegicus). Epidemiol Infect., 145(16), 3438-3448. https://doi.org/10.1017/S0950268817002539

Mulyono, A., Ristiyanto, Rahardianingtyas, E., Putro, D. B. W., \& Joharina, A. S. (2016). Prevalensi dan Identifikasi Leptospira Patogenik Pada Tikus. Vektora, 8(Nomor 1), 31-40.

Musser, G. (2014). A Systematic Review of Sulawesi Bunomys (Muridae, Murinae) with the Description of Two New Species. Bulletin of the American Museum of Natural History, 392, 1-313. https://doi.org/10.1206/863.1

Musser, G. G., \& Durden, L. A. (2014). Morphological and Geographic Definitions of the Sulawesian Shrew Rats Echiothrix leucura and E. centrosa (Muridae, Murinae), and Description of a New Species of Sucking Louse (Phthiraptera: Anoplura). Bulletin of the American Museum of Natural History, 391, 1-87. https://doi.org/10.1206/871.1

Narkkul, U., Thaipadungpanit, J., \& Srilohasin, P. (2020). Optimization of Culture Protocols to Isolate Leptospira spp. from Environmental Water, Field Investigation, and Identification of Factors Associated with the Presence of Leptospira spp . in the Environment. Tropical Medicine and Infectious Disease, 5(94), 1-11. https://doi.org/10.3390/tropicalmed5020094

Patterson, G., Martin, T. E., Adams, N., Cropper, O., Mustari, A. H., \& Tosh, D. G. (2017). Lowland rainforest bat communities of Buton Island, Southeast Sulawesi, including new regional records. Raffles Bulletin of Zoology, 65(February 2018), 373-385.

Polo, N., Machado, G., Rodrigues, R., Hamrick, P. N., Munoz-Zanzi, C., Pereira, M. M., ... \& Schneider, M. C. (2019). A one health approach to investigating Leptospira serogroups and their spatial distributions among humans and animals in Rio Grande do Sul, Brazil, 2013-2015. Tropical Medicine and Infectious Disease, 4(42), 1-20. https://doi.org/10.3390/tropicalmed4010042

Ramadhani, T., \& Yunianto, B. (2010). Kondisi Lingkungan Pemukiman yang Tidak Sehat Berisiko Terhadap Kejadian Leptopirosis (Studi Kasus di Kota Semarang). Suplemen Media Penelitian Dan Pengembangan Kesehatan, $X X$.

Ristiyanto, Farida, D., Gambiro, \& Wahyuni, S. (2006). Spot Survey Reservoir Leptospirosis Di Desa Bakung, Kecamatan Jogonalan, Kabupaten Klaten, Jawa Tengah. Buletin Penelitian Kesehatan, 34(3), 105-110. https://doi.org/10.22435/bpk.v34i3Sept.1207.

Ristiyanto, Handayani, F. D., Boewono, D. T., \& Heriyanto, B. (2014). Penyakit Tular Rodensia. Gadjah Mada University Press.

Ristiyanto, Wibawa, T., Budiharta, S., \& Supargiono. (2015). Prevalensi Tikus Terinfeksi Leptospira Interogans di Kota Semarang, Jawa Barat. Vektora, 7(2), 85-92.

Riyaningsih, R., Hadisaputro, S., \& Suhartono, S. (2012). Faktor Risiko Lingkungan Kejadian Leptospirosis di Jawa Tengah (Studi Kasus di Kota Semarang, Kabupaten Demak dan Pati). JURNAL KESEHATAN 
LINGKUNGAN INDONESIA, 11(1), 87-94. https://doi.org/10.14710/JKLI.11.1.87-94

Sandhu, R. S., Ismail, H. Bin, Hasni, M., Ja, B., \& Rampal, S. (2020). The Predictive Factors for Severe Leptospirosis Cases in Kedah. Tropical Medicine and Infectious Disease, 5(79), 1-8. https://doi.org/10.3390/tropicalmed5020079

Santhosh, S. R., Parida, M. M., Dash, P. K., Pateriya, A., Pattnaik, B., Pradhan, H. K., ... \& Lakshmana Rao, P. V. (2007). Development and evaluation of SYBR Green I-based one-step real-time RT-PCR assay for detection and quantitation of Japanese encephalitis virus. Journal of Virological Methods, 143(1), 73-80. https://doi.org/10.1016/j.jviromet.2007.02.011

Sendow, I., \& Bahri, S. (2005). Perkembangan Japanese Encephalitis di Indonesia. WARTAZOA, 15(3), 111-118.

Sendow, I., Ratnawati, A., Taylor, T., Adjid, R. M. A., Saepulloh, M., Barr, J., ... \& Field, H. (2013). Nipah Virus in the Fruit Bat Pteropus vampyrus in Sumatera, Indonesia. 8(7). https://doi.org/10.1371/journal.pone.0069544

Simpson. (1977). Too Many Lines: The Limits of the Oriental and Australian Zoogeographic Regions. Proceedings If the American Philosophical Society, 121(2), 107-120.

Sunaryo, \& Ningsih, D. P. (2014). Distribusi Spasial Leptospirosis Di Kabupaten Gresik, Jawa Timur. Buletin Penelitian Kesehatan, 42(3), 161-170.

Suyanto, A. (2001a). Penuntun Identifikasi Tikus di Jawa (Field Guide of Rats From Java). Fauna Indonesia, 5(1), $7-25$.

Suyanto, A. (2001b). Seri Panduan Lapangan : Kelelawar di Indonesia.

van den Hurk, A. F., Pyke, A. T., Mackenzie, J. S., Hall-Mendelin, S., \& Ritchie, S. A. (2019). Japanese encephalitis virus in Australia: From known known to known unknown. Tropical Medicine and Infectious Disease, 4(1). https://doi.org/10.3390/tropicalmed4010038

van den Hurk, A. F., Ritchie, S. A., \& Mackenzie, J. S. (2009). Ecology and Geographical Expansion of Japanese Encephalitis Virus. Annual Review of Entomology, 54(1), 17-35. https://doi.org/10.1146/annurev.ento.54.110807.090510

Villanueva, S. Y. A. M., Ezoe, H., Baterna, R. A., Yanagihara, Y., Muto, M., Koizumi, N., ... \& Yoshida, S. I. (2010). Serologic and molecular studies of Leptospira and leptospirosis among rats in the Philippines. American Journal of Tropical Medicine and Hygiene, 82(5), 889-898. https://doi.org/10.4269/ajtmh.2010.09-0711

Wiantoro, S. M. T., \& S. (2012). Indonesian flying foxes:research and conservation status update. A Journal on Zoology, 39(December), 103-113. https://doi.org/10.1016/j.apsusc.2004.05.020

Wijayanti, F., Humaerah, A. D., \& Fitriana, N. (2016). Potensi Kelelawar sebagai Vektor Zoonosis : Investigas berdasarkan Keanekaragaman Jenis dan Persepsi Masyarakat Terhadap Keberadaan Kelelawar di Kota Tangerang Selatan. Bioma, 12(1), 14-24. https://doi.org/10.21009/Bioma12(1).2

Wikipedia. (2020a). Muna Island. https://en.wikipedia.org/wiki/Muna_Island

Wikipedia. (2020b). Muna Regency. Wikipedia. https://en.wikipedia.org/wiki/Muna_Regency

Winoto, I., Graham, R. R., Nurisa, I., \& Hartati, S. C. M. (1995). Penelitian serologis Japanese Encephalitis pada Babi dan Kelelawar di Sintang, Kalimantan Barat. Buletin Penelitian Kesehatan, 23(3).

World Health Organization. (2018). Zoonoses.

\section{Copyrights}

Copyright for this article is retained by the author(s), with first publication rights granted to the journal.

This is an open-access article distributed under the terms and conditions of the Creative Commons Attribution license (http://creativecommons.org/licenses/by/4.0/). 